\title{
Quo Vadis English? The Post-Brexit Position of English as a Working Language of the EU
}

\author{
Elżbieta Kużelewska ${ }^{1}$ iD
}

Accepted: 25 September 2020 / Published online: 19 October 2020

(c) The Author(s) 2020

\begin{abstract}
"Brexit" as a word entered the European language's scene eight years ago as a term describing what seemed as a surrealistic scenario for the British. Since then, it has become the 'political word of 2016,' paved its way to the Oxford English Dictionary, and globally into the computer dictionaries which no longer underline it in red as an unknown term. 'Brexit,' as a political campaign motto, has also transformed into a realistic political strategy and eventually into a complicated, exhausting, dividing, yet finalized process. By the time it was accomplished, everyone in Europe was tired of it, but tiredness did not change the fact that Brexit was an historical period of turmoil of an unprecedented nature. Brexit occurred on a multitude of dimensions, including the EU language policy dimension. For the past 20 years, English has been by far the most commonly used language in the Union, not only as one of the 24 official languages of the Member States, but as a working language of all the institutions, all negotiations, and all political debates. This contribution aims to analyse the legal status and the practical dimension of the European Union working languages and to explore the position of the English language among them-both presently and with possible scenarios in the future Union, without the United Kingdom as the biggest English-speaking Member State. The initial assumption states that the geopolitical weight of the English language will diminish even if the Irish and Maltese will hold the language's position as an official language of the Union. In mathematical terms, there will be more native speakers in Hungarian or Slovak than in English. In political terms, Germany and France will have a chance to improve their influences by advocating for more efficient use of their languages. 'Quo vadis English?' seems a timely question to ask.
\end{abstract}

Keywords Brexit · Euro-English · Multilingualism · Official language · Working language $\cdot$ Varieties of English

No-one pays attention to what you say unless you speak English, because English is the language of power

Elżbieta Kużelewska

e.kuzelewska@uwb.edu.pl

1 Faculty of Law, University of Bialystok, Ul. Mickiewicza 1, 15-213 Białystok, Poland 


\section{Introduction}

Since February 1, 2020, after the United Kingdom's withdrawal, the European Union (EU) is composed of 27 Member States and 24 official EU languages. This paper will focus on Brexit's consequences for the EU, in particular on the legal status and the practical dimension of the EU working languages. It aims to explore the position of the English language among them-both presently and with possible scenarios in the future Union, without the United Kingdom (UK) as the biggest English-speaking Member State. ${ }^{1}$

Currently (and until the end of 2020 when the transition period in relations between the EU and the UK is to be finalized), the EU has 24 official languages. Their number is based on the principle of multilingualism, adopted by the EU and still considered valid, as well as on Regulation 1/1958 determining the languages to be used by the European Economic Community. All acts of EU primary law have official versions in all 24 official languages. Acts of secondary EU law are also drafted and/or translated in the 24 official languages. There are fewer official languages than Member States, as some share common languages. German, Greek, English, French, Dutch, and Swedish serve as official state languages in more than one country [26, p. 19].

Many papers have been devoted to the EU language policy [1, 7, 29, 30, 35, 20], the EU multilingualism principle $[6,1,63]$, and to descriptions of official and working languages of the EU [36, 32]. Nowadays, the situation is dynamic as the EU has lost one of its Member States and might lose one official language, which de facto played a role of a lingua franca in the European institutions.

According to the Regulation No. 1/1958 [79] (amended by Regulation No. $517 / 2013$ [17]) each Member State has the right to demand that its official language receive the status of an official language of the EU. It is Article 53 (1) of the Treaty on the European Union (TEU) [92] which enumerates the languages in which the Treaty is drawn up and shall be authenticated in. It currently contains 24 languages. English was notified as an official language only by the United Kingdom. The affirmation of equal status of languages of the Member States is contained in Art. 53 of the TEU, Art. 342 of the Treaty on the Functioning of the European Union (TFEU) [91], and in Art. 22 of the Charter of Fundamental Rights of the European Union [12]. According to EU law, there is no distinction between official and working languages. As a result, all official EU languages are also working ones. All languages are equal. However, in practice there are three languages most commonly used in the European institutions as the working ones - 'the big three'-English (the dominant one), French, and German [59, p. 216; 54, p. 43]. Before British accession to the EU, the French language had been particularly privileged and had been the sole official language of the European Coal and Steel Community established in 1951 and of the European Economic Community (EEC) built in 1957. For more than

\footnotetext{
${ }^{1}$ Gret Haller, Ombudsperson for Human Rights in Bosnia and Herzegovina; speech at a Council of Europe conference in 1999 on Linguistic Diversity for Democratic Citizenship in Europe, Innsbruck (Austria).
} 
20 years, French remained the language most frequently used among the Community partners [45, p. 62]. The leading role of the French language in the European Communities resulted from understandable reasons, such as French being an official language of three out of six founding Member States in that time. French was also the language of diplomacy and in fact, France was the largest Member State of the European Economic Community [57, p. 72]. French started to lose its dominance as the main working language after the EU enlargement in 1995. In 1996, for the first time, the use of English in the primary texts of the European Commission ran over that of French [93, p. 101]. Finally, the 2004 enlargement influenced the situation of the Union's official languages [45, p. 62]. The special status of English, especially within the European Commission, has been reinforced by the fact that English was used exclusively in all negotiations with candidate states [58, p. 157]. Consequently, English has reflected the socio-linguistic situation in the EU as the vast majority of EU citizens use English as a foreign language for modern communication. The citizens will always come first.

Once the UK leaves the EU and the transition period is over, English probably will no longer stay an official EU language. The question arises: whether English can be used as a working language? The initial assumption states that the geopolitical weight of the English language will diminish even if the Irish and/or Maltese decide to hold the language's position as an official language of the Union. In mathematical terms, there will be more native speakers in Hungarian or Slovak than in English. In political terms, Germany and France will have a chance to improve their influence by advocating for more efficient use of their languages. 'Quo vadis English?' seems a timely question to ask.

This paper is composed of five parts. Section 1 starts with a short introduction to multilingualism and linguistic diversity in the EU. Section 2 analyses legal basis for English as an official language, both nowadays, as well as in the post-Brexit Union. Section 3 is devoted to varieties of English, including Euro-English. Section 4 discusses arguments in favour of keeping English as a working language in the EU after the UK exit. Finally, Sect. 5 will draw some conclusions.

\section{Brief overview of multilingualism and linguistic diversity in the EU}

The process of multilingualism started in 1958 when the European Council declared all languages of the Member States official and working languages of the European institutions. Back then it was politically impossible to designate one official language of the Community from among languages of the founding Member States. Choosing German language was not an option due to temporal proximity of the two world wars. French would not have been accepted by the Flemish because of Belgium's linguistic diversity, nor by the Italians because of equality issues. After the Second World War, the founding members tried to avoid any potential conflict. "As the language issue had a direct impact on the question of national identity, the choice to opt for multilingualism encompassing all languages was both the most obvious and the least conflictual. European multilingualism thus began with four official languages: German, French, Italian and Dutch" [9, p. 2]. 
The appointment of Leonard Orban in 2007 as the commissioner for multilingualism is recognised as significant "step in institutionalising multilingualism as an official policy area within the EU" [80, p. 21]. The motto of the EU- "unity in diversity"-reflects preservation of identities, cultural values, history and also national languages of the Member States. Diversity is understood as a crucial component of unity [81, p. 12]. The Council is responsible for the EU language regime, by unanimous vote. The principle of multilingualism adopted by the EU in its documents guarantees the language equality and equal rights of the EU citizens to access to legal documents in their national languages. The EU citizens enjoy the fundamental democratic rights to understand the applied EU law in their own languages and to equal access to European institutions without language barriers [4, p. 3].

The EU egalitarian language policy is a unique example of fully democratic language policy implemented in international organisation. The EU encourages linguistic pluralism and cultural diversity [96, p. 119] as the EU's 500 million citizens speak more than 60 national, regional and minority languages and it is hard not to agree with Phillipson that "language is a sensitive political issue, as it is a profound symbol of national and personal identity" [75].

The institutional EU language policy had been working successfully as long as membership in the EU was limited; the growing number of Member States brought along some difficulties in this respect as more languages were added to the "official language" group [15, p. 272]. Enlargement of the EU set a challenge to the legislator and provoked questions about limitation the official languages of legislative acts to a small number of the most broadly spoken languages. According to House, the EU language policy is ineffective and hypocritical [42]. Officially all EU languages are equal, however some of them seem more equal than others and some languages are more "international" than others. As a result, the equality of all EU official languages is a kind of a myth. Moreover, language equality refers only to the EU official languages. It is not a universal principle as it does not respect the principle of equality for all the languages spoken in the EU Member States [88, p. 152] (e.g. Catalan, Basque, Corse). Minority languages, apart from the policy of their protection and promotion, have different status in the Member States [77, pp. 21-22; 72, pp. 106-113]. Although there are 24 EU official languages, in fact, English is a lingua franca in the EU. In the name of linguistic equality, the EU promotes illusory policy of languages equality [42]. For this situation House blames the French who cannot accept the recession of French as linguistic power, translators' lobbies interested in keeping status quo and the politically-correct ideologies against the concept of English as a European lingua franca [42]. Thus, the question why the EU does not agree to one common language keeps returning. The answers are consequently the same: first, the EU's aim is to protect the linguistic diversity and language rights recognised as fundamental European values and the core of European democracy [52, pp. 4-5]; second, it could provoke "anglicization of Europe" [76, p. 60], even if linguistic diversity complicates political dialogue and the exchange of ideas. 


\section{Legal Basis for English as an Official Language in the EU}

Regulation 1/1958 does not explicitly state whether more than one official language may be declared by a Member State. The original version of the regulation in French indicates that this is not possible. The same applies to the English version of the document [79]. Articles 3 and 8 of Regulation 1/1958 specify (by using the word 'language' in the singular) that a Member State may have only one language for communication with the EU. Article 3 provides: 'Les textes adressés par les institutions à un État membre ou à une personne relevante de la jurisdiction d'un État member sont rédigés dans la langue de cet État' (Documents which an institution of the Community sends to a Member State or to a person subject to the jurisdiction of a Member State shall be drafted in a language of such State); Art. 8 similarly provides: "En ce qui concerne les États membres où existent plusieurs langues officielles, l'usage de la langue sera, à la demande de l' État intéressé, determiné suivant les règles générales découlant de la législation de cet État" (If a Member States has more than one official language, the language to be used shall, at the request of such State, be governed by the general rules of its law).

Literal interpretation provides that each Member State has the right to choose one mother tongue which will be the official language in the EU. Presently, the EU has 24 official languages as each Member State nominates one. The UK was the only Member State that named English as its official language. There are two other Member States that commonly use English, but they have notified a different language as their EU official language-Ireland nominated Irish (Gaelic), Malta nominated Maltese. Upgrading Irish and Maltese to the status of an official EU language has a symbolic meaning reflecting on identity [90, p. 70]. However, very few Irish speak Irish as their first language, whereas nearly all Maltese speak equally Maltese and English as their first language. According to the Regulation $1 / 1958$ and the present statement of the Council, once the UK leaves, English is likely to no longer be an official language. The exit of the UK from the EU causes not only a reduction in the number of Member States, but also a decrease in the number of official languages.

Therefore, it is difficult to maintain English as an official language if the notifying country withdraws from the EU. As each Member State can choose only one official language, English will stop to be EU official language as only UK nominated it as its official. According to Ginsburgh and Moreno-Ternero, there are three possible (and debatable) scenarios for saving the current status of English as official (and working) language of the EU. First, "To argue that it is the language that disenfranchises the smallest number of EU citizens, and that it probably is the most spoken language in the world" [38, p. 4]. Second, to replace by Malta and Ireland their EU official language (Maltese and Irish) by English. Third, to convince Luxembourg to nominate English as its official EU language. All above options provoke many doubts. The second solution, even if accepted by Malta and Ireland, does not guarantee that the decision of the EU Council will be unanimous. The third option seems completely unlikely. There are three official 
languages in Luxembourg: Luxembourgish, French and German. Nominating English as EU official language by Luxembourg would seem at least as artificial and a bit of stretch gesture. English will cease to be an official language of any Member State, but it will still be used as a mother tongue by five million Irish and 460,000 Maltese. Even if Ireland and Malta nominate English as an official language, it will have fewer native speakers than Hungarian or Slovak. Ireland and Malta as states small in size and population are less influential in the EU comparing with the big players such as France or Germany.

However, it should be stressed that Regulation 1/1958 is a secondary, not primary law of the EU. Primary law, such as the Treaty on the Functioning of the EU in Art. 342, clearly expresses: 'The rules governing the languages of the institutions of the Union shall, without prejudice to the provisions contained in the Statute of the Court of Justice of the European Union, be determined by the Council, acting unanimously by means of regulations.' This provision includes two significant rationales. First, the Council is responsible for drafting and proposing of the rules regarding the language(s) of the EU. Second, this regulation must be adopted unanimously by all 27 Member States after the UK exits from the EU. Is there any chance that the representatives of the Member States in the Council will vote unanimously on preserving English, not only as an official, but also as a working language? This situation is, admittedly, possible and legally permissible. The agreement of all Member States would sanction the status of the English language in the EU institutions. However, with the exit of the United Kingdom, 60 million English native speakers leave the Union, making the other official EU languages more valuable and significant [37]. In this instance, Ireland and Malta could notify English as a second language, but this would risk opening up difficult regional claims (Catalan, Basque, Corsican, Breton, etc.). It is no coincidence that none of the countries have indicated its intention to do so [73].

English could continue to be a working language if other Member States agree to it. At the same time, the EU Member States-France and Germany-are reluctant to accept keeping the dominant position of English and suggest the need to increase the role of French and German as working languages. They believe English, as a main working language, will be limited. The French president Emmanuel Macron wants French to replace English in the EU institutions as it was before the UK joined the EEC in 1973. He claimed that, 'English is not destined to be the only foreign language Europeans speak' [3]. The return of French as the primary working language seems to be an interesting and fortunate perspective for France, especially when at least $80 \%$ of the European Commission officials speak French as a first, second, or third language [97]. At the same time, this idea might not be very attractive to other EU Member States. French is no longer recognised as a global (European) language. The majority of EU citizens do not speak French [44, p. 65]. Then again, there are counterarguments listed by Francophones. They stress the necessity of a rebalance between languages which, without excluding English, would give preference to French. French is the language spoken by 130 million Europeans, including 19 of the 27 EU states, which have joined the International Organization of La Francophonie [70]. Why a language becomes a global one does not have much to do with the number of people who speak it. It has more to do with who those speakers 
are. There must be a link between language dominance and economic, political, and cultural power. Without a strong power base, no language can make progress as a global medium of communication [18, p. 7].

German, in turn, would be advantageous for the respective native speakers and disadvantageous for non-native speakers, in particular, in preparation of texts and communicative impacts [2]. The position of Germany (and of German) grew significantly in the1990s after the reunification of the two German states, and in 1995 when Austria joined the Union with German as an official language [14, p. 3]. Presently, Angela Merkel wishes for more German to be spoken in the European Parliament, the Commission, and the Council [87].

\section{English or Englishes?}

English is the language spoken by the English people and by non-English people in many other states [40, p. 93]. According to the functional range and the norms of correctness, one can distinguish English as a native language, as a second language, as a second dialect and as a foreign language [39, p. 19]. The common Standard (British) English core has developed to Englishes. There are various regional subvarieties-British English, Irish English, American English or Mid-Atlantic [65], Indian English, Australian English, Canadian English or even European English. Standard English is based on the South-East Midlands dialect of a prominence as it was used in XV century in London, at the Court and the universities of Oxford and Cambridge [78, p. 26]. For Trudgill, Standard English is usually used in print and normally taught in schools and to non-native speakers learning the language [94, p. 5]. At present, Standard English is a pluricentric language [62, p. 445]. Kachru distinguishes three categories of users of English: (1) the 'inner circle' with native speakers for whom English is a mother tongue and to most of them the only language they know; (2) the 'outer circle' comprising second-language speakers who use English as the other tongue in everyday communication; (3) the 'expanding circle' of people who use English as another tongue, e.g. as a foreign language [49, pp. 356-357]. In the context of nowadays, European Union English seems to be relevant for 'inner' and 'expanding' circles [22, p. 25]. For years Europe has been categorized as a part of the 'expanding circle' of learners of English with no legitimate variety of their own. Since the late 1990s. this perception started to be challenged with debates on legitimizing European English [68, p. 4].

In 1980s for the first time European English was proposed as a possible variety of English [30, pp. 49-66]. In 1993 Décsy in focused on the development of a European form from English and called it 'Eurish' [19]. Today, Eurish is a fusion of English with other European languages within the EU [89]. The term 'Euro-English' was originally used by Carstensen in 1986 [10, p. 832]. For Carstensen, the EuroEnglish was an interesting phenomenon as English language spoken by European politicians was different from the real daytime English usage that was its original model.

Euro-English is a new variety of English in the process of its formation [51, p. 14]. Many non-native speakers of English in Europe use this language; thus, it 
makes it possible to term the English language widely spoken in Europe as 'EuroEnglish'. According to Mollin, Euro-English can be recognised as a variety of English in Europe and sufficiently fulfils "the linguistic and sociolinguistic criteria distinguishing learner English from an endonormative variety" [68, p. 12]. EuroEnglish has some specific features and lexis, e.g. euro, Euro zone, Euro area, Member States, four freedoms, Euroscepticism, Berlaymont (as a red tape), internal market $[33$, p. 453]. These words are commonly used in the EU, however, they might not be understood by persons unfamiliar with the EU context. A new status of English language in Europe can be observed in its vocabulary and structure. As Fenyő rightfully points out, the new lexical elements demonstrate euro-mania-vocabulary which contains many words with euro element [84, p. 61]. It is also defined as Eurospeak-English characterised by usage of the EU jargon. The style of English in the EU now and in the future is likely to diverge from 'native' British norms [7, p. 4]. Euro-English or Eurish is still English, but it has its own features that are often common to both Roman and Germanic languages. One characteristic feature is the European uncountable noun-singular in native-speaker English but plural in Eurish: "he received feedbacks", "we have a lot of informations" and "we are producing online contents" [85]. According to Modiano, continental Europeans are developing their own variety of English, a process that will accelerate when the United Kingdom leaves the European Union and continental Europeans pay less attention to British rules of what is right or wrong in the language rules [66, pp. 319-324]. Maybe one day, Euro-English could, like American or Australian English, even have its own dictionary.

\section{Speak English or Die? Why English Should Remain a Working Language of the EU}

There are several reasons why English should be kept as a working language.

First, English is a lingua franca. There are many definitions of English as a lingua franca. The simplest and most useful for the purpose of this paper is a definition given by Seidlhofer: a lingua franca is a language used to communication in English between speakers with different first languages [82]. English is used in the EU internationally as a lingua franca and takes on second-language proprieties [67, p. 19]. English is the language which dominates as first foreign language in the EU Member States educational systems. Therefore, it has become the working language of many of the EU's transnational teams and networks [96]. English is more and more frequently used between non-native speakers. The EU is composed of several different Member States, different cultures and has 'Europeanized resonance' [74, p. 26]. English is a lingua franca as it is used for academic and professional communication. It is a language of science, technology, popular culture, media and globalization.

Second, English reflects the socio-linguistic situation in the EU. The dominance of the English language in the EU institutions has so far not been directly linked to UK membership in the EU, but to the language skills of the EU staff and the knowledge of English by ordinary people. English is the dominant language not only in the 


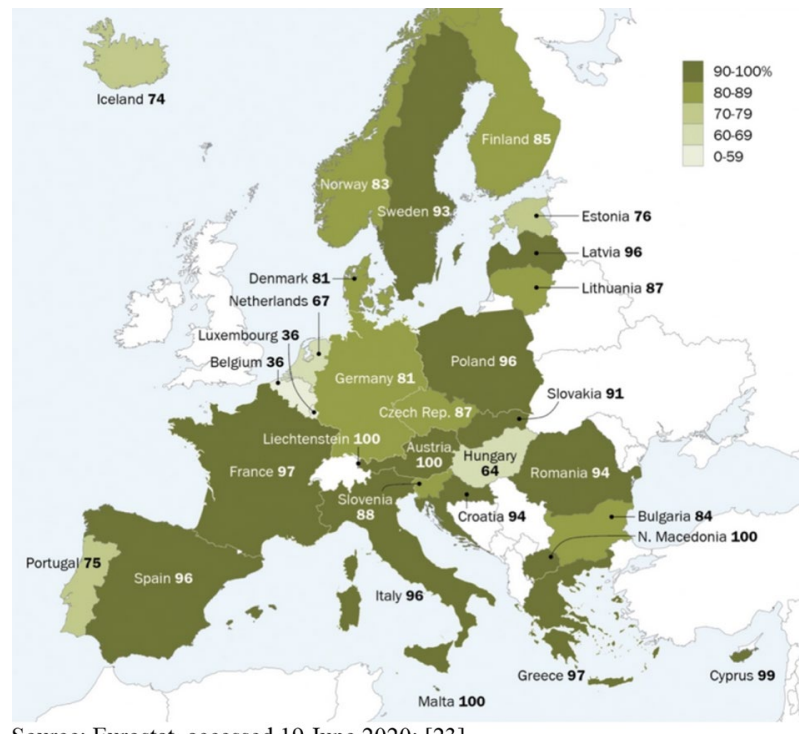

Source: Eurostat, accessed 19 June 2020; [23].

Figure 1. Percentage of all students learning English in school in 2017 [23, 27]

EU institutions, but also among regular people. English is the most spoken foreign language not only in the EU, but also in the world [36, p. 6]. Eurobarometer data of 2012 [24] and 2016 [25] show that the five most widely used foreign languages by citizens of EU Member States are: English, French, German, Spanish, and Russian.

According to Eurostat data [27], English is the most studied language in Europe. 91\% of students in primary and secondary schools were studying English in 2017. English is a compulsory foreign language in nearly all education systems in the EU. The number of its users is systematically increasing [5, p. 41]. The Council approved the European Commission's recommendation of the ' $1+2$ language policy' whereby EU citizens should learn at least two foreign languages and their own mother tongue [8, p. 213]. The Council's recommendation of May 2019 on a comprehensive approach to the teaching and learning of languages have been published and strongly encourages speaking at least two languages other than one's mother tongue [16]. Ireland and the United Kingdom are the only countries where learning a foreign language at school is not compulsory. Apparently, only one in five Europeans can speak two languages other than their own [46]. The popularity of English as a foreign language in European schools now and in recent years means that young Europeans are much more able to communicate with others than their parents and grandparents were [11, p. 28]. Yet, "The small margin by which English was ahead of German and French as a learned language in the generation born before the second war has been turned into a huge gap in the younger generation, with secondary competence in English now five times more common than secondary competence in German or French, and with over double as many secondary speakers of English as secondary speakers of all other languages taken together" [95, pp. 8-9] (Fig. 1). 
French is the second most learnt foreign language in European countries (learnt by $15 \%$ of students in school). German is the third most learnt foreign language in education in 2017 (11\%), followed by Spanish (9\%) and Russian (2\%). In comparison with European statistics data (2014), there has been a significant decrease in the number of students learning languages other than English. In 2012, English was studied by $97.1 \%$ of students, French by $34 \%$, German by $22 \%$, and Spanish by $12 \%$ [29].

Third, the EU official documentation (including legally binding acts such as treaties, directives or regulations as well as non-binding documents such as reports, recommendations, opinion, etc.) is translated and published in all EU official languages. Loss of the status of an official language means that acts are not translated into English. It is difficult to imagine that the EU-a major player in a global market of 500 million inhabitants-would not have its legislation and economic agreements available in the language of world trade. I cannot agree more with Alfred Hayes, who stated in 1920 that, "the supremacy of the French language in diplomacy and the English tongue in trade is due to no direct action on their behalf, but is merely accidental accompaniment of the national character and genius in their special fields" [41, p. 199]. In fact, English is a lingua franca for international trade or at least the leading candidate to play this role [55, pp. 250-251].

Fourth, a compromise would be to leave English as the official language for international trade, but to intensify the use of French and German in the European institutions. English is a lingua franca not only in the EU, but also in the entire world. English is the (global) language of communication, as well as between the EU and the rest of the world. English, as a common foreign language, enables us to communicate in everyday life, in the trade of goods and services, and the provision of information [35, p. 8]. Moreover, English is a language of business and international negotiations for the foreseeable future.

Fifth, the use of English as the main language of communication in EU institutions after Brexit could have a positive impact. The EU-27 would use a neutral language for communication, without preferring any of the official languages of its Member States. This would ease tensions between Member States with regard to discussions on which official language should be used as a working one. As Wright points out, a common language is a common good that benefits all. However, when a common language is the mother tongue of one of the groups benefiting, this is unfair, because its members do not need to pay for the common good [96]. In addition, in the post-Brexit EU, the English-speaking multilinguals would pose a higher percentage of English speakers than nowadays [61, p. 73]. The post-Brexit situation is a win-win situation for the non-native English speakers [47 p. 32]. No other official EU language would be privileged. This is especially true as the English currently used in European institutions is not the classic British English, but rather Euro-English. Since there are a lot of variations of English and people adopt them for their own purposes [71, pp. 22-29], the variety of the Euro-English might be a successful tool. The European variety of English (known as Euro-English, European English, Brussels-English, or even Continental English) would promote legitimacy for the EU institutionally and support speech community within the EU. This would perfect the idea of two kinds of language: languages for communication and 
languages for identification [43, pp. 559-560]. Language for communication stands for an instrument for making oneself understood in international meetings. Language for identification is related to identity, such as literature, culture, history, and the arts [64, p. 129].

Euro-English might serve as a language for communication (a working one). Other EU official languages would serve as languages for identification and strengthen the cultural identity of particular Member States especially that language is perceived as the prime marker of national identity in Europe [68, p. 58]. English is not a "killer language" that works to the detriment of other European languages [69, p. 8]. The situation where there are only $1 \%$ of English native speakers in the EU may provoke and cause a development of English varieties instead of protecting the integrity of British English. However, linguistic changes are rather slow, complex processes and need time. European English could be an official medium of communication with its own standards for lexical use, grammar, spelling and punctuation [66, p. 321] in the future. The EU would be using a neutral language in its communication without preferring any of the official languages of its states [86]. Perhaps, over time, Brussels-English will be one of the 'New Englishes' languages [60]. Nevertheless, it is worth remembering the words of Andy Hamilton: 'Once Latin was everyone's second language, it was no longer anyone's first' [83]. The former Italian Prime Minister and European commissioner-Mario Monti-in 2017 said that English should become the EU's main official language once the UK leaves the Union, French should be side-lined and English given a more prominent role [20].

Sixth, exclusion of English from European circles would result in disorder and enormous costs, it would deprive Europe of part of its identity, and seriously reduce opening EU citizens up to the world. Replacing English with French, German, or any other language would require the EU to invest enormously in training of the translators. Remaining English as a sole lingua franca would definitely reduce the costs of translation (and interpretation) and promote bigger efficiency in communication relative to the existing communicative regime [31, p. 33].

\section{Conclusions}

There are many indications that in the new European Union (one without the United Kingdom), the geopolitical importance of the English language will be lower than in the past. English will likely cease to be an official EU language of any Member State. It will be used as a mother tongue by five million Irish and 460,000 Maltese (a total of $1 \%$ of the EU inhabitants). Even if Ireland and Malta choose English as an official language, it will have fewer native speakers than Hungarian or Slovak. Both Ireland and Malta are small and not influential states in the EU compared to France or Germany. Certainly, France and Germany will use Brexit to strengthen their languages in EU institutions. It would be a surprise if Germany and Austria or France and French-speaking Belgium were to support the status quo of the current dominance of the English language.

One of the reasonable arguments for keeping English as a working language is the adoption of Euro-English. A common foreign language such as European English 
would provide for an added value as it would facilitate trade in Europe, improve the opportunity for political participation of EU citizens, and support communication in the European public sphere. A common foreign language as a working one would create trust among people and it would not exclude the EU from the rest of the world, especially in terms of trade relations which shape the international relations as such. As Modiano points out, "In the act of recognising the validity of EuroEnglish, one liberates continental European [second language] users of English from the tyranny of standard language ideology" [48]. Using English, all EU citizens will be communicating in a second language, not mother tongue. Hence, only a narrow group of people (Irish and Maltese) will be unfairly advantaged.

On the other hand, multilingualism and linguistic diversity are the fundamental principles of the EU. The EU language policy supporting linguistic diversity can be recognised as opposite to the promotion of the Euro-English language. European society is excused from the threat of dominance from one language. English hegemony, as the EU's lingua franca, may cause reasonable resistance. However, all $24 \mathrm{EU}$ official languages would still exist and reflect the cultural and sovereign identities of the Member States. Adoption of a single foreign language as a working one would be only a desired completion. Using English as a lingua franca in Europe would not hinder linguistic diversity, it would unite more than it divides, because it could be "owned" by all Europeans-not in a cultural meaning, but as means of enabling understanding. If native speakers of e.g. French and English can use their mother tongues, how can one ensure equivalent (linguistic) rights for others? The question "quo vadis English" remains open: should it be a neutral language for communication in the EU and between the EU and the outside world? Remaining English as a neutral language should be acceptable by EU Member States and would correspond to the EU's official language policy on the preservation of language diversity.

Open Access This article is licensed under a Creative Commons Attribution 4.0 International License, which permits use, sharing, adaptation, distribution and reproduction in any medium or format, as long as you give appropriate credit to the original author(s) and the source, provide a link to the Creative Commons licence, and indicate if changes were made. The images or other third party material in this article are included in the article's Creative Commons licence, unless indicated otherwise in a credit line to the material. If material is not included in the article's Creative Commons licence and your intended use is not permitted by statutory regulation or exceeds the permitted use, you will need to obtain permission directly from the copyright holder. To view a copy of this licence, visit http://creativecommons.org/licen ses/by/4.0/.

\section{References}

1. Ammon, Ulrich. 2006. Language conflict in the European Union. On finding a politically acceptable and practicable solution for EU institutions that satisfies diverging interests. International Journal of Applied Linguistics 16 (3): 319-338.

2. Ammon, Ulrich. 2020. The Position of the German Language in the World. Abingdon-New York: Routledge.

3. As Britain Leaves, English on Rise in EU-to French Horror.2018. POLITICO. https://www.polit ico.eu/article/french-english-language-brexit-european-parliament-ecj-commission-eu-next-water loo/ Accessed 19 June 2020. 
4. Baaij, Jaap. 2018. Legal Integration and Language Diversity. Rethinking Translation in EU Lawmaking. Oxford: Oxford University Press.

5. Berns, Margie, Marie-Thérèse Claes, Kees de Bot, Riet Evers, Uwe Hasebrink, Ineke Huibregtse, Claude Truchot, and Per van der Wijst. 2007. English in Europe. In The Presence of English: Media and European Youth, ed. Margie Berns, Kees de Bot, and Uwe Hasebrink, 15-42. Berlin: Springer.

6. Bhatia, Tej K., and William C. Ritchie (eds.). 2014. The Handbook of Bilingualism and Multilingualism. Oxford: Blackwell Publishing Ltd.

7. Bolton, Kingsley and Daniel R. Davis. Brexit and the Future of English in Europe. https://deepblue. lib.umich.edu/bitstream/handle/2027.42/139103/weng12263_am.pdf?sequence=2\&isAllowed=y. Accessed 19 September 2020.

8. Branchadell, Albert. 2007. The language of the Europe is translation. An interview with Karl-Johan Lönnroth. Quaderns. Revista de tradducio 14: 207-215.

9. Buzmaniuk, Stefanie. 2019. Parlerl'européen. Question d'Europe 541: 1-6.

10. Carstensen, Broder. 1986. Euro-English. Linguistics across Historical and Geographical Boundaries 827-836: 2020. https://doi.org/10.1515/9783110856132.827.

11 Cheschire, Jenny. 2002. Who We Are and Where We're Going: Language and Identities in the New Europe. In Beyond Boundaries Language and Identity in Contemporary Europe, ed. Paul Gubbins and Mike Holt, 19-34. Clevedon: Multilingual Matters Ltd.

12. Charter of the Fundamental Rights of the EU, Official Journal of the European Union C 326; 26.10.2012.

13. Chua, Catherine Siew, and Kheng, (eds.). 2018. Un(intended) Language Planning in a Globalising World: Multiple Levels of Players at Work. Warsaw-Berlin: de Gruyter.

14. Clyne, Michael G. 1995. The German Language in a Changing Europe. Cambridge: Cambridge University Press.

15 Cogo, Alesia, and Jennifer Jenkins. 2010. English as a lingua franca in Europe. A mismatch between policy and practise. European Journal of Language Policy 2 (2): 271-294.

16. Council Recommendation of 22 May 2019 on a comprehensive approach to the teaching and learning of languages. Official Journal of the European Union. 2019C/189/3. https:/eur-lex.europa.eu/ legal-content/EN/TXT/PDF/?uri=CELEX:32019H0605(02). Accessed 20 June 2020.

17. Council Regulation (EU) No 517/2013 of 13 May 2013. adapting certain regulations and decisions in the fields of free movement of goods, freedom of movement for persons, company law, competition policy, agriculture, food safety, veterinary and phytosanitary policy, transport policy, energy, taxation, statistics, trans-European networks, judiciary and fundamental rights, justice, freedom and security, environment, customs union, external relations, foreign, security and defence policy and institutions, by reason of the accession of the Republic of Croatia, OJ L 158, 10.6.2013, p. 1-71.

18. Crystal, David. 2003. English as a Global Language. Cambridge: Cambridge University Press.

19. Décsy, Gyula. 1993. Europe's Linguistic Future: The Eurish-Problem. Eurasian Studies Yearbook 65: 7-18.

20. de la Baume, Maïa.As Britain leaves, English on rise in EU - to French horror,https://www.politico. eu/article/french-english-language-brexit-european-parliament-ecj-commission-eu-next-waterloo/. Accessed 25 August 2020.

21. Dendrinos, Bessie. 2018. Multilingualism language policy in the EU today: A paradigm shift in language education. Training, Language and Culture 2 (3): 9-28. https://doi.org/10.29366/2018t 1c.2.3.1.

22. Dolerup, Cay. 1996. English in the European Union. In The English Language in Europe, ed. Reinhard Hartmann, 24-36. Oxford: Intellect Ltd.

23. Devlin, Kat. 2020. Most European Students Learn English in School. 9 April 2020, https://www. pewresearch.org/fact-tank/2020/04/09/most-european-students-learn-english-in-school/ Accessed 16 June 2020.

24. Eurobarometer 2012 no. 386. https://ec.europa.eu/commfrontoffice/publicopinion/archives/ebs/ ebs_386_en.pdf Accessed 12 June 2020.

25. Eurobarometer 2016 no. 243. https://data.europa.eu/euodp/data/dataset/S518_64_3_EBS243 Accessed 12 June 2020.

26. European Commission/EACEA/Eurydice, 2017. Key Data on Teaching Languages at School in Europe - 2017 Edition. Eurydice Report. Luxembourg: Publications Office of the European Union.

27. Eurostat 2017. Foreign Language Learning Statistics. https://ec.europa.eu/eurostat/statisticsexplained/index.php/Foreign_language_learning_statistics. Accessed 12 June 2020. 
28. Eurostat. https://ec.europa.eu/eurostat/statistics-explained/index.php/Foreign_language_learning _ statistics. Accessed 14 June 2020.

29. Eurostat. https://ec.europa.eu/eurostat/search?p_auth=rZAZUQxr\&p_p_id=estatsearchport let_WAR_estatsearchportlet\&p_p_lifecycle $=1 \&$ p_p_state $=$ maximized\&p_p_mode $=$ view \&_estat searchportlet_WAR_estatsearchportlet_theme=empty\&_estatsearchportlet_WAR_estatsearchport let_action=search\&_estatsearchportlet_WAR_estatsearchportlet_collection=empty\&text=english. Accessed 14 June 2020.

30. Ferguson, Charles. 1982. Simplified Registers and Linguistic Theory. In Exceptional Languages and Linguistics, ed. Lorraine K. Obler and Lise Menn, 49-66. New York: Academic Press.

31. Ferguson, Gibson. 2018. European language policy and English as a lingua franca: a critique of Van Parijs's 'linguistic justice'. In Using English as a Lingua Franca in Education in Europe, ed. Zoi Tatsioka, Barbara Zeidlhofer, Nicos C. Sifakis, and Gibson Ferguson, 28-50. Berlin-Boston: De Gruyter Mouton.

32. Fidrmuc, Jan, and Victor Ginsburgh. 2007. Languages in the European Union: The quest for equality and its cost. European Economic Review 51 (6): 1351-1369.

33. Forche, Christian R. 2012. On the emergence of Euro-English as a potential European variety of English: Attitudes and interpretations. Jezikoslovlje 13 (2): 447-478.

34. Gazzola, Michele. 2006. Managing Multilingualism in the European Union: Language Policy Evaluation for the European Parliament. Language Policy 5: 393-417.

35. Gerhards, Jürgen. 2014. Why the EU should Change its Language Policy. Making the Case for Promoting English as Europe's Lingua Franca. BSSE Working Paper No. 32. Berlin: Freie Universität Berlin. https://nbn-resolving.org/urn:nbn:de:0168-ssoar-427107. Accessed 19 June 2020.

36. Ginsburgh, Victor, Juan D. Moreno-Ternero, and Shlomo Weber. 2017. Ranking languages in the European Union: Before and after Brexit. European Economic Review 93: 131-159.

37. Ginsburgh, Victor, Juan Moreno-Ternero and Shlomo Weber. 2018. The Fate of English in the EU After Brexit: Expected and Unexpected Twists. https://voxeu.org/article/english-language-eu-after -brexit. Accessed 18 June 2020.

38. Ginsburgh, Victor, and Juan D. Moreno-Ternero. 2019. A Lingua Francain the Post-Brexit EU. ECARES working paper 22: 1-17.

39. Görlach, Manfred. 1998. Varieties of English world-wide: Where we stand. Links \& letters 5: 13-36.

40. Han, Ligan. 2019. A review of the major varieties of English language. International Education Studies 12 (2): 93-99.

41. Hayes, Alfred E. 1920. The English language and international trade. Journal of the Royal Society of Arts 68 (3508): 198-209.

42. House, Juliane. 2001. The Language Policy in the European Union, Guardian Weekly, 19 April 2001. https://www.theguardian.com/education/2001/apr/19/languages.highereducation. Accessed 21 September 2020.

43. House, Juliane. 2003. English as a lingua franca: A threat to multilingualism? Journal of Sociolinguistics 7 (4): 556-578.

44. House, Juliane. 2008. English as lingua franca in Europe today. In Multilingual Europe: Facts and Policies, ed. Guus Extra and Gurk Dorter, 63-86. Berlin-New York: Mouton de Gruyter.

45. Hnízdo, Bořivoj. 2005. More Languages, Less French? The Enlarged EU and the Status of French as an EU Language. Perspectives 24: 61-68.

46. In Europe, Speaking More than One Language is Still a Privilage.2019. https://www.europeanda tajournalism.eu/eng/News/Data-news/In-Europe-speaking-more-than-one-language-is-still-a-privi lege. Accessed 20 June 2020.

47 Jenkins, Jennifer. 2018. Trouble with English? In Languages AfterBrexit How the UK Speaks to the World?, ed. Michael Kelly, 25-34. Cham: Palgrave Macmillan.

48. Johnston, Ian. 2017. Brexit Could Create A New Language - Euro-English.Independent 20 September. https://www.independent.co.uk/news/science/brexit-latest-news-language-euro-english-uk-leave -eu-european-union-a7957001.html. Accessed 21 September 2020.

49. Kachru, Braj. 1992. The Other Tongue. English Across Cultures. Urbana: University of Ilinois Press.

50. Károly, Adrienn. 2008. Language Policy in the European Union. Eger Journal of English Studies 8: 125-141.

51. Khokhlova, Irina. 2017. Euro-English: A new variety? International Journal of Research in Engineering and Social Sciences 7 (4): 14-18. 
52 Kjaer, Anne Lise and Silvia Adamo. 2016. Linguistic Diversity and European Democracy: Introduction and Overview. In Linguistic Diversity and European Democracy, eds. Anne Lise Kjaer and Silvia Adamo, 1-16. London and New York: Routledge.

53. Komorowska, Hanna. 2015. The European Language Policy and the Teaching Profession in the 21st Century. Studia Linguistica Universitatis Iagellonicae Cracoviencis 132 (3): 135-150.

54 Krzyżanowski, Michał. 2009. Discourses about Enlarged and Multilingual Europe: Perspectives from German and Polish National Public Spheres. In Language, Discourse and Identity in Central Europe The German Language in a Multilingual Space, ed. Jenny Carla and Patrick Stevenson, 23-50. London: Palgrave Macmillan.

55. Ku, Hyejin, and Asaf Zussman. 2010. Lingua Franca: The Role of English in International Trade. Journal of Economic Behavior \& Organization 75 (2): 250-260.

56. Křepelka, Filip. 2012. Between Legitimacy and Efficiency Recent Developments of Language Regime in the European Union. In The Challenges of Modern Democracy and European Integration, ed. Elżbieta Kużelewska and Dariusz Kloza, 101-116. Warszawa-Białystok: Aspra.

57. Kużelewska, Elżbieta. 2011. Proces ratyfikacji Traktatu ustanawiajacego Konstytucję dla Europy $i$ jego następstwa. Warszawa: Aspra.

58. Kużelewska, Elżbieta. 2014. Unity in Diversity. The Language Policy of the European Union. Studies in Logic, Grammar and Rhetoric 38 (51): 151-165.

59. Kużelewska, Elżbieta. 2019. Impact of Brexit on the status of English language in the European Union. Środkowoeuropejskie Studia Polityczne 2: 213-227.

60. Lim, Lisa, and Umberto Ansaldo. 2016. Languages in Contact. Cambridge: Cambridge University Press.

61. Mac Giolla, Diarmait, and Chríost Matteo Bonotti. 2018. Brexit, Language Policy and Linguistic Diversity. Cham: Palgrave Macmillan.

62. Mair, Christian. 2007. Varieties of English around the world: Collocational and cultural profiles. Phraseology and Culture in English 54: 437-470.

63. Mamadouh, Virginie. 2020. The Geopolitics of Multilingualism in the European Union. Abingdon: Taylor \& Francis.

64. Michaud, Matthew, and Bradley D.F. Colpitts. 2015. English as a Lingua Franca: Globalisation, Ownership, and the Diversification of English. KwanseiGakuin University Humanities Review 20: $125-131$.

65 Modiano, Marko. 1996. The Americanization of Euro-English. World Englishes 15 (2): 207-215.

66. Modiano, Marko. 2017. English in a post-Brexit European Union. World Englishes. https://doi. org/10.1111/weng.12264.313-327.

67. Modiano, Marko. 2020. Teaching English in a European and Global Perspective. Cambridge: Cambridge Scholar Publishing.

68. Mollin, Sandra. 2006. Euro-English Assessing Variety Status. Tübingen: Gunter Narr Verlag.

69. Motschenbacher, Heiko. 2013. New Perspectives on English as a European Lingua Franca. Amsterdam-Philadelphia: John Benjamin Publishing Company.

70. Mushikiwabo, Louise. 2020. Après le Brexit, la primauté de l'anglais peut-elle perdurer alors qu'il ne figure plus parmi les langues officielles de l'Union?.https://www.lemonde.fr/idees/artic le/2020/02/06/apres-le-brexit-la-primaute-de-l-anglais-peut-elle-perdurer-alors-qu-il-ne-figure-plusparmi-les-langues-officielles-de-1-union_6028573_3232.html. Accessed 22 June 2020.

71. Nunan, David. 2015. Standard English, English Standards: Whose Standards Are They in English Language Education? In English Language Education in a Global World,ed. Lap Tuen Wong and AditiDubey-Jhaveri, 22-29. New York: Nova Science Publishers.

72 Núñez, Martinez MaríaAcracia. 2013. The Protection of Minority Languages at the European Level. Revista de Derecho Político 87: 101-128.

73. Qatremer, Jean. 2020. UE: après le Brexit, la fin de l'unilinguisme anglophone?.https://bruxelles. blogs.liberation.fr/2020/02/16/ue-apres-le-brexit-la-fin-de-lunilinguisme-anglophone/. Accessed 22 June 2020.

74. Peckham, Donald W. 2015. Towards Ongoing and Using English: Issues of Identity and Community for English as a Foreign Language Learners. In European Encounters: Language, Culture and Identity, ed. Irén Annus, 19-34. Szeged: JATEPress.

75. Phillipson, Robert. 2001. English Yes, But Equal Language Rights First. Guardian Weekly, 19 April 2001 https://www.theguardian.com/theguardian/2001/apr/19/guardianweekly.guardianweekly1. Accessed 12 September 2020. 
76. Phillipson, Robert. 2016. The EU and languages: Diversity in what unity? In Linguistic Diversity and European Democracy, eds. Anne LiseKjaer and Silvia Adamo, 57-74. London and New York: Routledge.

77. Piccoli, Lorenzo. 2011. The European Union and minority languages: Evolution, achievements and contradictions in the light of the Treaty of Lisbon. Interdisciplinary Political Studies 190: 20-30.

78. Pichler, Pia and Satori Soden. 2012. Varieties of English. https://lgslib.files.wordpress.com/2015/11/ en2001-varities-of-english.pdf. Accessed 18 September 2020.

79. Regulation no. 1 determining the languages to be used by the European Economic Community. 1958. Official Journal of the European Communities 0J 17; 6.10.1958, 385/58. https://eur-lex.europ a.eu/legal-content/EN/TXT/PDF/?uri=CELEX:31958R0001\&qid=1592390547988\&from=en. Accessed 19 June 2020.

80. Schjerve, Rindler, and Eva Vetter Rosita. 2012. European Multilingualism: A highly fragmented and challenging field of research. In Linguistic Diversity in Europe. Current trends and Discourses, ed. Patrick Studer and Iwar Werlen, 21-47. Berlin: De Gruyter Mouton.

81 Rindler-Schjerve, Rosita, and Eva Vetter. 2012. European Multilingualism. Current Perspectives and Challenges. Bristol, Buffalo, Toronto: Multilingual Matters.

82 Seidlhofer, Barbara. 2005. English as a lingua franca. ELT Journal 59 (4): 339-341. https://doi. org/10.1093/elt/cci064.

83. Setter, Jane. 2019. Will Brexit Spell the End of English as an Official EU Language?.https://www. theguardian.com/commentisfree/2019/dec/27/brexit-end-english-official-eu-language-uk-brussels. Accessed 18 June 2020.

84. Sarolta, Simigné-Fenyô. 2003. The Function of the English Language in the European Union. European Integration Studies, Miskolc 2 (2): 53-64.

85. Skapinker, Michael. 2018.Will Europeans end up speaking Eurish?https://www.straitstimes.com/ opinion/will-europeans-end-up-speaking-eurish. Accessed 17 September 2020.

86. Sommsich, Réka. 2016. What Language for Europe? ELTE Law Journal 1. https://eltelawjournal. hu/what-language-for-europe/. Accessed 21 June 2020.

87. Sprechen Sie Deutsch? Merkel wants more German spoken in the EU.https://www.euractiv.com/ section/languages-culture/news/sprechen-sie-deutsch-merkel-wants-more-german-spoken-in-eu/ Accessed 21 June 2020.

88. Strubell, Miquel. 2007. The Political Discourse on Multilingualism in the European Union. In The Language Question in Europe and Diverse Societies, Political, Legal and Social Perspectives, ed. Dario Castiglione and Chris Longman, 147-181. Oxford: Hart Publishing.

89. Sykes, Selina. 2015. Do you Speak Eurish? EU has Its Own Language... and It's Far Too Difficult for the Rest of Us.https://www.express.co.uk/news/world/606416/European-Union-Eurish-langu ages-Europe-English. Accessed 16 September 2020.

90. Szul, Roman. 2015. (In)Equality of Languages in the EU and its Economic and Political Consequences. Politeja 31 (2): 67-80.

91. Treaty on Functioning of the European Union, Official Journal of the European Union C326; 26.10.2012.

92. Treaty on the European Union, Official Journal of the European Union C326; 26.10.1012.

93. Truchot, Claude. 2003. Languages and Supranationality in Europe: The Linguistic Influence of the European Union. In Languages in a Globalising World, ed. Jacques Maurais and Michael A. Morris, 99-110. Cambridge: Cambridge University Press.

94. Trudgill, Peter. 2000. Sociolinguistics: An Introduction to Language and Society. London: Penguin.

95 van Parijs, Philippe. 2011. Linguistic Justice for Europe and for the World. Oxford: Oxford University Press.

96. Wright, Sue. 2000. Community and Communication. The Role of Language in Nation State Building and European Integration. Clevedon: Multilingual Matters Ltd.

97. Zeman, Carleigh. 2019. EU Bids the UK Adieu: The Impact of Brexit on the Language of the Law in the European Union. North Carolina Journal of International Law. https://ncilj.org/blog_posts leu-bids-the-uk-adieu-the-impact-of-brexit-on-the-language-of-the-law-in-the-european-union .Accessed 20 June 2020.

Publisher's Note Springer Nature remains neutral with regard to jurisdictional claims in published maps and institutional affiliations. 